\title{
Bhagavad Gita: The Paradox of Dharma and its Ontology
}

\author{
Abilash Chandran Ramchandran *
}

\begin{abstract}
In the history of Indian philosophy, dharma has been reevaluated and challenged multiple times by various schools of thought: is it is an injunction from above or one codified in scriptures? What happens when a scripture is authorless and what is then the validity of dharma? Can one follow dharma if it brings unfavorable results? It is in this context that Bhagvad Gita attempts to deal with dharma in a fictional context of a battle and in doing so raises more complex questions - it addresses the very paradox laying at the heart of dharma in a paradoxical manner. This paper looks at dharma in an ontological sense: the living dharma of Gita is a significant intervention, since Gita attempts to explain and thus justify the paradox of one's being by proposing life of living dharma (not living a life of dharma).
\end{abstract}

Keywords: Dharma and Gita, Ontological Paradox

\section{Introduction}

Dharma is not paradoxical in its application, its very proposition as a moral construction is intended to address the paradox lying at the crux of being. Bhagvad Gita, probably the most popular as well as controversial text in Indian philosophical tradition further explores the nuances of dharma in action; Gita, interestingly does not freeze life as a block of existence on earth that can be studied in isolation

\footnotetext{
* CHRIST (Deemed to be University), Bangalore, India; abilashchandran.r@christuniversity.in
} 
and viewed as unchanging and stable; rather it proposes life in action (not life in thought) as an unstable and undefinable phenomenon, within which dharma is subjected to a serious ontological and moral inquiry; it assembles, in the context of a fluid state of existence called battleground where one's life, honour and rights at stake. Various logical arguments used, in Indian philosophy thus far, to call upon dharma to answer various questions of moral choices and give an ontological twist to it. The dharma of Krishna in Gita is not the dharma of academic deliberations rather it is the dharma of living in the purest form; it is not the dharma of 'life' but the dharma of 'living' (as Heidegger was famous for having delineated death from dying) that Krishna recommends as the solution to the philosophical roadblock Arjuna has come upon as he looks at the vast number of relatives, family members and friends he is supposed to slay to achieve his ends. As Nagarjuna in Mulamadhyamakakarika establishes emptiness itself as inessential and thus one's noticing of the inessentiality of being itself is inessential, Krishna in Gita puts forth the deeply paradoxical nature of dharma's construction as a notion/ injunction/moral code by means of further more paradoxically poetic utterances. This had engendered many controversies, much misunderstanding and appropriation of Gita by various philosophical, political and social agencies through the history of India. This paper argues that this paradoxical engagement with a paradoxical construct is quite deliberate and it requires an intervention from Heideggerian concepts of da-sein and being-inthe-world to render the arguments of Krishna in a modern philosophical sense.

\section{Is There One Morality to Hinduism?}

Dharma is not a unilateralal ethical code - it is "an all-embracing concept ... diffuse as it has many and varying meanings, ranging from 'ordinance, usage, duty, right, justice, morality, virtue, religion, good works, function or characteristics' to 'norm', 'righteousness', 'truth' and much else" (Bilimoria, 2007, p. 37).

Christopher Key Chapple, while erroneously claiming that Buddhism and Jainism as a part of the "rich tapestry of many traditions: some theistic, others not; some life-affirming, others 
ascetics", he does rightly point out the problem of Indian ethics aka dharma - dharma can be embedded to one's birth status while one can redefine one's dharma and its repercussions via focused action (Chapple, 2007, p. 351). He associates the power discourse embodied by the caste system with the philosophy of dharma and rebirth. One cannot refute who one is born as (according to Chapple this strand of rebirth and caste came with the Aryan invasion), but one can act and change one's dharma and ensure a better birth next time.

This then is the "action-oriented morality" that dharma is. Even so, karma and rebirth are so irretrievably intertwined, so much that one almost looks like the other. Karma means action. Narratives of karma "teaches responsibility of one's actions" and those of rebirth a "continuity of action that goes beyond the boundaries of finite biography" (Chapple, 2007, p. 351). In popular parlance, karma is at times meant to be the repercussions of previous action, which in a way confuses rebirth with karma. But there is another word for "the residue left by a particular action" - samskara (352). Let us look into why such misassociations happen (since it is important for an understanding of karma).

Action is of two kinds: afflicted (klista) and unaffflicted (aklista). The former causes repeated suffering; the latter allows one to be liberated from repeated sufferings and frustrations (dukha) of the past. In either case, responsibility for one's actions lies within oneself; as proclaimed in the Yogavasistha, it is indeed possible to overcome the negative influences of the past through concerted action in the present (Chapple, 2007, p. 352).

Karma is one's action in this life, but this life is a minuscule segment in an undivided continuity of temporality, which is rebirth. Rebirth could be metaphorical since one is supposed to act to liberate oneself from this continuity of temporality. If rebirth is not biological, is it a signifier of the being of the ever-pervading consciousness - the Brahman as seen by a human perceiver? No. This is the being of the Brahman that is unrealised yet, as it is reborn multitudinously. Now, your unrealised karma could be a continuity within an undivided stream of continuity; while continuity works against continuity (by discontinuity) it continues to go with it. Dharma, if it is "to be" in the continuity and then to 
attempt to liberate one from it by "being" dispassionately in it, becomes deeply paradoxical and problematic.

\section{Non-violence, Violence and Dharma}

Jainism as well as Buddhism, parallel discourses to Hinduism, look at dharma in the manner of partial or full detachment from forceful actions (mental, physical and both as one) as an impediment to dharma. As per Jainism, violence is an "agitated activity ... said to impair one's innate consciousness, bliss and energy". Jainist philosophy is in a sense a philosophy of the world in a Heideggerian sense. That is, your being in the world is accessed as you live in it, since the world's being calls unto you. In Jainism, all things (even inanimate) possess "life force" (jiva). Chapple (2007) asserted, "by impairing the consciousness, energy and bliss of rocks and grass as well as air, water and fire bodies through acts of violence, karma adheres to one's own jiva, preventing the ascent to pure aloneness". This "pure aloneness" could be non-separation from the life, its spatial and temporal presence around us. As an initiation into the life of "pure aloneness", a Jain is advised to practise "restraint of mind, control of tongue, carefulness on roads, removing things from roads, and eating in daylight" (Chapple, 2007, p. 354).

Buddhism advocated reverance to life and it promotes kindness to all living beings. This compassion is advocated not in itself but since it enables minimal "involvement in the world" (Chapple, 2007, p. 355). It is a middle path of existing in the world (not renunciation alone) while not disturbing the order of life and nonlife (since non-living entities are not distinguishable from our being).

\section{Cosmic Person, Totality in Marriage with Rebirth in Vedic Hinduism}

Rigveda's definition of life is in terms of a cosmic man, made up of "four transactional arenas, corresponding to the various tasks required for the operation of the world. At the top ... is Brahmin, the teacher and the priest. ... The next group, the Ksatriyas, are identified with the arms and serve as warriors and politicians. The 
Vaisyas or merchants are associated with the thighs, the workers or sudras with the feet." The use of the human body here is a signifier for the cosmic whole, which enables our being. This signifier later came to stand for reciprocity of social relationship. Bhagavad Gita is such a later text that extols the cosmic whole that is society itself, made of people playing various varying roles. In Gita, this societal role play provides one with a chance to disavow the ethical repercussions of highly unethical actions such as murder, that too of one's kin and kith. The paradox here being you belong to your role as a killer of the enemy forces but you don't belong to the role permanently and thus you haven't sinned. Here ethics is truly distinguishable with dharma, as dharma, in a vein similar to that of Jainism, is ontological. Here detached violence is not a convenient mechanism proposed to wash off sin of committing a crime (Arjuna claims to Krishna that killing one's kith and kin would further destroy the moral fabric of a ksatriya clan, it is a sin that would haunt him forever as well.). The paradox is already built into the system of Indian moral philosophy, and Bhagvad Gita merely employs it (not invents it), to justify action over non-action.

According to Chapple, much later, in a societal sense caste system came to be justified by the signifier of the cosmic whole of a man. Theontological rebirth then becomes biological one, as a low born person could not protest since he is paying dividends to his karma of the previous birth. Bilimoria claims that dharma parallels Hegel's idea of Sittlichkeit - an ethical behaviour, which is set in tradition and custom. The individual would merely imitate and habituate to the ethical code, which is a set of objective laws of a community. But in case of Indian tradition, the objective (and nondifferentiating) code of dharma came to evolve into "an overall form to a system of positive law and regulations of individuals and of groups..." (Bilimoria, 2007, p. 38). This systematic, societally controlling mechanism came to be the caste system (though caste system is not our concern here, since dharma is embroiled in justifications of caste, its discussion is unavoidable).

Again Dharma is not the objective set of rules that one is obliged to blindly follow. A person in the third avenue of purusartha (dharma) could realise that he has finished observing his duties and move on to the fourth avenue (moksa) - a decision he takes by 
relying on his meditative and coginitive insights. So while dharma is imposed as a societal code of rules, it is also determined by the cognitive capability of a superior person. Dharma then is to be obliged with as well as resisted. As Daya Krishna (2007) suggests, purusartha could be a signifier of no specific moral signification and it could be a mere myth. Dharma encapsulates this paradox, which is why Krishna teaches Gita to Arjuna upon whom the question of what dharma is as an individual dawns - should he kill as a Kshatriya or renunicate as a Brahmin only could?

\section{Dharma as the Paradoxical Authorless Imperative}

Jaimini in his Mimamsasutra claims dharma to be of the nature of an injunction. The sutra 1.1.2 defines dharma as that which is known by the codana sentences. Dharma is not an abstract notion in one's head, it is not an instinct inciting us to act ethically, rather in more precise terms it is "that sentence which incites a person to act" (Sabara indirectly quoted by J.N. Mohanty, 2007, p. 59). As we go further into the nuances of the definition, an interesting paradox emerges. While a dharma is an injunction, not every injunction is a dharma. "The sentence must be valid or prama. Only the imperatives enjoined by the scriptures possess the unquestionable validity - either because their author is free from any defect or because they are just authorless (apaureseya)" (Mohanty, 2007, p. $60)$. The injunction is supposed to carry an order from a specific authority, but here this authority is empowered only to be disempowered as he is already rendered a non-author. His commanding authority is valid only so far it abides by the scripture, but it is interesting to note that the dharma as put forward by the scriptures is also bound to be "authorless". This standpoint does resonate with the understanding of sentence structure by the classical Indian grammarian Panini. According to him the subject of a sentence is not the primary agent, since it is not truly independent as we assume in, say, English grammar. 


\section{Bhagvad Gita as Negotiating Ground of Two Conflicting Trends}

Bhagvad Gita's place in the history of Indian philosophy is significant in the sense of it addressing the central conflict of trends that attempt to define the agency of dharma. Until then, the will to perform an action was supposed to be caused by either the injunction from above (society, religion, the sovereign, the scriptures) (sabdibhavana) or the things designated by words (arthibhavana). The authorless theory of Mimamsa (apauruseya), the Bhatta theory, the concept of Vacaspati, the Nayaya theory all take up one of the position to define the causal efficiency of an action. This is quite significant in realizing one's will to dharma and the very nature of dharma. For a long time, the philosophers have fought over this issue from two opposing camps. Badari claimed that one may perform a duty irrespective of whether or not it brings favourable results. Prabhakara later revived this view by considering the result as supersensible with the action itself supersensible in nature. That is while you follow an objective imperative, you also have the favorable result in mind, though this objective goes beyond your personal needs and goals. Thus causal efficiency is impersonal in a personal way and personal in an impersonal way. Sri Krishna in Bhagavad Gita further revived this paradoxical nature of dharma as he advises Arjuna to do his duty without considering the consequences of his action, according to J.N. Mohanty.

\section{Dharma of Non-dharma in Bhagvad Gita}

Bhagvad Gita begins its narrative with a vision of both the Pandava and Kaurava armies placed one against the other. According to the 10th century philosopher Abhinava Gupta, the two armies signify awareness and lack of awareness. Pandavas, representing awareness, co-exist with Kauravas, signifiying the lack of awareness. It is important to note that awareness does not wipe away the other - in fact dharma can be realised with one coming to face the paradox of their co-existence. Arjuna comes to be the face of this enlightenment since he is the one who is caught the most between the two opposing vectors. 


\begin{abstract}
"There are two types of people in this world who are not suitable to receive instruction. The first are the ignorant ones who do not possess even the smallest knowledge. The second are those who have eliminated ignorance in its entirety. ... The best candidate for instruction is a person who has doubts about the topic that is going to be presented." (Marjanovic, 2004, p. 30).
\end{abstract}

It is interesting that those who have eliminated ignorance still cannot achieve realisation since knowledge could either make one abide by the internal dharma (cognitive insight) or external dharma (societal duties and other codes). Dharma as put forward by Krishna, then, is a killing of all dharmas (as Abhinava Gupta interprets it in terms of the term 'dharmakshetra' - kshetra meaning destruction, where 'kshad' the root word means 'to kill'), which can only be conceptualised when you have a person in the grey space (Arjuna), right in the middle of the battle field, belonging neither here or there.

According to Bilimoria, Bhagavad Gita resolves the traditional conflict between the anti-action proponents of pre-Vedic era (Nivrtti of ascetic) and the pro-action proponents of the social and moral codification of life (pravrttti of the worldly). It synthesises action and non-action with the discourse of niskama karma or disinterested action. Bilimoria observes that Gita's role in Indian philosophy is to "conserve Brahmanical cultural pattern (the pravrtti ideal) and integrate the threatening asocial ethic of asceticrenunciation (the nivrtti ideal)..." (Bilimoria, 2007, p. 45). Devdutt Pattanaik (2015), on the other hand, believes that Gita was written to successfully negotiate with the rising popularity of Buddhism (promoting ascetism) and provide a middle path for the householder in the Hindu fold. What is significant is that regardless of the specific social function of the text it addressed the paradox at the heart of dharma and how it pushed the sociocultural boundaries with regard to nivrtti and pravrtti to redefine dharma at a metaphysical level. 


\section{Ambedkar on Gita: A Counter-Revolutionary}

Ambedkar is famous for his claim on Gita that "if Krishna were to appear as a lawyer acting for a client who is being tried for murder and pleaded the defence set out by him in the Bhagvat Gita there is not the slightest doubt that he would be sent to the lunatic asylum" (Kuffir, 2011). Ambedkar hits the nail on its head, doesn't he? One of the major ethical problems with the Gita as moralistic philosophy is that it criticizes non-violence and advocates violence, if (of course) read literarily. Krishna claims that it is his duty as a kshatriya to kill and disregarding his duty would be spiritually debilitating. It is wrong, unethical and sinful to kill - this is not just a modern secular view; according to Ambedkar, most people influenced by Buddhism, had bid adieu to violence and had begun subverting the varna principle, as the shudras took up sanyas, inspired by Buddha. What Gita does in this context is to reinstate the belief in the varna system and nullify the ethical question hanging over acts of killing by certain communities during war - it releases the tension of ethical conundram by saying that killing could be right if called upon by Vedic edicts and, spiritually, if done dispassionately. This stance helped defuse the buildup of anti-Vedic mood in India at the time.

To go back to the central conflicts in Gita, to kill or not seems to be the most important problem - Krishna builds the case of killing as a human construct but most of humanity has evolved to disapprove of killing, while the instinct to kill and destroy is alive in all of us; when it comes to actual killers though we expect them to repent later most of them need much orientation to practice repentance. For example, Ajmal Kasab (Dastane, Shaikh, Tanksale, Isalkar, \& Hafeez, 2012), the 2008 Mumbai terror attack co-perpretator, who had jointly killed 72 civilians, was hardly repentant during investigation, trial and even in jail awaiting his death sentence he was seen singing songs (until he was seen barely muttering a prayer seeking forgiveness at his gallows). The 2008 murder case in which Abhrami, a young woman from Tamil Nadu, poisoned her two children to death to elope with her lover and was later arrested and convicted is another such instance. Let me quote from a newspaper report (Palani, n.d.): 
“'How was your mind state at that time?' was asked by the lawyer to Abhirami to which she reportedly said 'Everything happened. I could not forget that incident. I am dying daily without getting sleep because of that sinful act. Please don't ask me anything more' cried Abhirami".

In the statement "everything happened" she suggests that the murder happened in a blur, though there was elaborate planning, to some extent. She is guilty and repents now because the society condemns it, but it is almost impossible to feel something is sinful when you sin because sin is a construction of social injunction from above - sabhdibhavana. Dharma in Indian tradition is also considering whether an action would bring favorable results, which can be vaguely called arthibhavana. You could sin even when it favours you as an individual, though the societal codes forbid it. So you sin and flee, as Abhirami attempted and failed. This conflict between the two voices is difficult to negotiate at times, also since life just 'happens', including a sinful act. So while Abirami might have planned the homicide she didn't do it because of it; action is quite a slippery road as most of the times we do not know why we act in a certain manner. Abirami would not be able to forget the incident since she will never truly understand her mind at the moment of the crime - it was a mindless moment. Though as much as we want to believe otherwise, life permeates boundaries of moral and social codes. Though murder / killing is inconvenient and unacceptable according to present-day legal and moral systems, the human phenomenon in the middle of the debate constantly subverts these systems. Whether right or wrong, Gita provides an avenue to discuss this human phenomenon, 'dispassionately', as it is amoral and nonjudgemental in apprising human action in extremes. The very paradox of the appraisal emerges from the fact that it is both human to be passionate and dispassionate in action, while it is not humane to be so.

Yes, Krishna could be sent to the lunatic asylum but this entire world is one such asylum, which means it is significant to address (rather than summarily dismiss) the conflict between simultaneous passionate and dispassionate approaches to an action and the problems they engender. 


\section{Gandhi's Gita - Dharma as Renunciation and Non- Violence}

Gandhi makes it clear that Mahabharata (including Gita) does not endorse violence or warfare; in fact it shows the futility of violence, he claims. The violence that Krishna invokes is only metaphorical it is an undetached action, not necessarily violent always (or in his context it is violent in an acceptable sense - he never calls for unwarranted killing in the Gita). Also violent action too performed by a yogin ceases to be so. But it is extraordinary how Gandhi makes peace with the amoral war endorsement of Krishna while recasting Gita in the warp of his ideology of non-violence, thus addressing the essential paradox at the heart of the treatise. For example, he defines action as service to humanity and says that one telling beads is not spiritually benefitting unless one serves people by means of work and there work becomes a means in itself (not engaging in social service so that one could see God). It is interesting since Gandhi is oriented towards the process that the result in his politics - if there is a right way of doing something he would follow it even if that does not yield immediate practical benefits. "He who gives up action falls. He who gives up only the reward rises. But renunciation of the fruit in no way means indifference to the result." (Gandhi, 2009, p. 44). So, his action is, paradoxically, a counter-active action. The goal is always a convenient pointer for the direction the action has to take but it is not decider or the purpose of the action.

Coming to violence, Gandhi can be seen resisting the claim that violence can be performed without attachment: "[...] according to the Gita, all acts that are incapable of being performed without attachment are taboo. ... According to this interpretation murder, lying, dissoluteness, and the like must be regarded as sinful and thereby taboo." (Gandhi, 2009, p. 47). It is quite obvious Gandhi is here contesting Krishna's claim that murder can be done without it being a sin, if you kill for no gain in mind. Unlike Krishna who claims that even extreme acts can be done with absolute withdrawal from the fruits of it, Gandhi believes that human violence always emerges from greed, fear and hatred and so it 
always engenders attachment and thus it is a sin to kill. He says (Gandhi, 2009),

"Let it be granted that, according to the letter of the Gita, it is possible to say that warfare is consistent with renunciation of fruit. But after forty years' unremitting endeavor fully to enforce the teaching of the Gita in my own life, I have, in all humility, felt that perfect renunciation is impossible without perfect observation of ahimsa in every shape and form." (Gandhi, 2009, p. 52)

\section{Heidegger and the Nishkamakarma of Krishna}

The seemingly irresolvable puzzle of the idea of selfless but still self-oriented, super-social but still socially bound duty proposed in Bhagvad Gita could be unravelled, to some extent, via the theory of da-sein and being-in-the-world by Martin Heidegger. For that purpose let me briefly put across what Heidegger means by these two concepts:

\subsection{Da-sein and Being-in-the-World}

(A) Da-sein is a literal translation is 'being-there'. According to Heidegger, it is "an anticipatory drive- towards-Being, thrown-asyet-to-be-realized (in-the-world) with beings (it encounters in the world)." "Da" (there) is important "here". There means the "world". The "world" in Heidegger means the non-binary physicality of our existence with the world (The world in quotes is the world you are not separate from at the time you drive towards it; it is the world of your being). One cannot have the being realized without the physicality that trails, sets around, and in which we exist; Therebeing is also time blending into the world. It is a spatiotemporal existence, to put it in simple terms. For, example, "a girl eating a banana on her way to a bus stop" is in the "da", the "there" (on her way to...). But this "there" could exist because the girl is "there"; the girl is "there" because she "is" there - the time is important "here". And the time is not just realized in the verb "is" - it is realizing in "eating", not just eating but eating a "banana", which places her in her world, in her time, one within the other in such a way that it 
becomes "one-within-the-other", and the girl is "girl-eating-abanana-on-her-way-to-the-bus-stop".

(B) Being-in-the-world means dealing with the world, as we understand the latter in Heideggerian terms. Every moment a person is situated in the time and space of this world he or she is accessing his da-sein. It begins with a baby, just delivered, screams out after breathing in the air of the world. It's scream is its being-inthe-world, when only the baby, its bed or cradle, its first few moments of life (its temporality in the world) exist, and it is exulting at the prospect of its da-stein. Krishna in Bhagvad Gita wants Arjuna to realise that his "world" is the battlefield (and nothing else), like the cradle is for the baby, and his scream is the volley of arrows he would shoot at his enemies. He is not and he won't be separate from his arm that holds the bow, the bow that shoots the arrow, the air that carries it swiftly across, the body that is the target, the immense pain of the victim, the blood that surges in the archer's vein and that simultaneously spews out of the victim's wound are all fused together in one time and space, and that is the realisation of Atman in one's day-to-day existence, be it the killer or the killed. Arjuna's duty is to realise this oneness again and again in almost detached state, and his battle cry will then be no different from the first scream of a newborn-in-the-world.

Yes the conflict still exists and the paradox of existence continues but only outside of one's existence. Yes it is scary and shocking to equate birth with death, but that is what Krishna repeatedly does in Chapter 2 of Bhagvad Gita. The shock derives not even from the equanimity of these two extremes but the laying bare of the inner paradox of considering the opposites in one context.

\section{The Question of the Mortification of Death in Nishkamakarma}

J.N. Mohanty (2007) raises a question in terms of whether it is right to place dharma above the what it entails in reality - the contents of an act of dharma. In case of Bhagvad Gita it is death. Is "the domain of values ... structured like a pyramid with a higher [goal] at the top"? (Mohanty, 2007, p. 67) Since Mohanty approaches it from Kantian and Hegelian moral concepts the hierarchy and over 
abstractification appears to be a prominent fault of the model. But seen ontologically, one realises that the contents of an action is not to be separated and seen as a component. Once you are in da-sein the components cease to exist and even the world isn't a mere space to hold you in, but you are in-the-world-doing-something-in-time. Here the hierarchy of placing a higher good as a purpose of the dharmic action above all doesn't happen. There is no hierarchy in Heidegger's "world". Death too then is not mortifying in itself, but it can be so in the world. It is the mortification-of-the-body-in-theworld and one does not take mortification apart and question it as the da-sein is what keeps drawing you in the world not piecemeal analysis of life.

To conclude, it is important to state that no reading of Gita can be expected to make it rational, humanistic or progressive since as a text engaging with the highly paradoxical entity in India moral philosophy called dharma it attempts a radical position by using highly paradoxical and poetic utterances that defer meaning once uttered and defy it too. Using paradox as a tool to engage with the very paradox of dharma in a state of not life but of living Krishna shows it promotes the most vigorous form of being-in-the-world while also remaining ethically feasible to the given context. By staying detached in living one realises da-sein as well as meets ethical standards. Again, by choosing living over the "technological" form of it called life Krishna further complicates the many ways of performing dharma. One can say that Krishna here truly lives up to his reputation as not just a problem solver and a smart negotiator of differences but also a trouble maker.

\section{References}

Bilimoria, P. (2007). Early Indian ethics-Vedas to the Gita; dharma, rites to ‘Right'. In P. Bilimoria, J. Prabhu, \& R. Sharma (Eds.), Indian ethics: classical traditions and contemporary challenges (vol. 1, pp. 3355). Ashgate Publishing Ltd.

Chapple, C. K. (2007). Action oriented morality in Hinduism. In P. Bilimoria, J. Prabhu, \& R. Sharma (Eds.), Indian ethics: classical traditions and contemporary challenges (vol. 1, pp. 351-361). Ashgate Publishing Ltd. 
Dastane, S., Shaikh, A., Tanksale, M., Isalkar, U., \& Hafeez, M. (2012, November 22). Yerwada Jail: Kasab loses composure at gallows, seeks forgiveness. Mumbai News - Times of India. Retrieved August 12, 2019, from

https://timesofindia.indiatimes.com/city/mumbai/Kasab-losescomposure-at-gallows-seeks-forgiveness/articleshow/17315569.cms

Gandhi, M. (2009). Introduction. In J. Stohmeier (Ed.), The Bhagvad Gita according to Gandhi. North Atlantic Books.

Gupta, B. (2006). Bhagavad Gìtā as duty and virtue ethics: Some reflections. Journal of Religious Ethics, 34(3), 373-395.

Heidegger, M. (1996). Being and time (Joan Stambaugh trans.). State University of New York Press, Albany.

Krishna, D. (2007). The myth of ethics of purusartha or humanity's lifegoals. In P. Bilimoria, J. Prabhu, \& R. Sharma (Eds.), Indian Ethics: Classical traditions and contemporary challenges (vol. 1, pp. 103115). Ashgate Publishing Ltd.

Kuffir. (n.d.). What does Dr. Ambedkar say about the Bhagvat Gita? Round Table India. Retrieved from http://roundtableindia.co.in/index.php?option=com_content\&view= article\&id=4347:essays-on-the-bhagwat-gita-philosophic-defence-ofcounter-revolution-krishna-and-hisgita\&catid $=119$ :feature\&Itemid $=132$

Marjanovic, B. (Ed.). (2004). Abhinavagupta's commentary on the Bhagavad Gita: Gitartha-samgraha. Indica Books.

Mohanty, J.N. (2007). Dharma, imperatives, and tradition: toward an indian theory of moral action. In P. Bilimoria, J. Prabhu, \& R. Sharma (Eds.), Indian ethics: classical traditions and contemporary challenges (vol. 1, pp. 57-78). Ashgate Publishing Ltd.

Palani, D. (n.d.). Abirami struggling to sleep-Chennaiyin Adaiyalam. Chennai Times. Accessed on 12 Aug 2019.

Pattanaik, D. (2015). My Gita. Rupa Publications. 